\title{
KARAKTERISTIK FRUIT LEATHER DENGAN VARIASI RASIO BUAH NAGA MERAH (Hylocereus polyrhizus) - PEPAYA (Carica papaya L.) DAN SUHU PENGERINGAN
}

\author{
FRUIT LEATHER CHARACTERISTICS WITH THE RATIO OF RED DRAGON \\ (Hylocereus polyrhizus) - PEPAYA (Carica papaya L.) VARIATION AND DRYING \\ TEMPERATURE
}

\author{
Fikha Andita Puspitasari, Merkuria Karyantina, Yannie Asrie Widanti \\ Fakultas Teknologi dan Industri Pangan Universitas Slamet Riyadi, Surakarta \\ Jl. Sumpah Pemuda 18 Joglo Kadipiro Surakarta 57136 \\ E-mail: fikhaandita555@gmail.com
}

\begin{abstract}
ABSTRAK
Buah naga merah merupakan buah tropis yang kaya akan antioksidan, namun kurang disukai karena rasanya yang tidak begitu manis. Buah naga merah juga sangat mudah mengalami kerusakan karena kandungan kadar air yang tinggi. Fruit leather adalah jenis olahan produk makanan yang berasal dari bubur daging buah yang dikeringkan sampai kadar air berkisar 10-15\%. Pembuatan fruit leather memerlukan buah yang memiliki kandungan serat yang tinggi. Tujuan dari penelitian ini adalah untuk mengetahui karakteristik fruit leather dengan perbandingan buah naga merah dan pepaya serta mengkaji suhu pengeringan yang tepat untuk mendapatkan karakteristik fruit leather yang baik.

Perlakuan yang diberikan meliputi perbandingan buah pepaya: naga merah, yaitu 20:80, 30:70, dan 40:6o. Perlakuan yang kedua adalah suhu pengeringan, yaitu 140,150 , dan $160^{\circ} \mathrm{C}$. Hasil penelitian menunjukkan bahwa perbandingan buah naga merah - pepaya dan suhu pengeringan berpengaruh nyata terhadap karateristik kimia dan organoleptik fruit leather. Berdasarkan tujuan penelitian diperoleh fruit leather terbaik pada perlakuan perbandingan daging buah pepaya:daging buah naga (20:80) dan suhu pengeringan $140^{\circ} \mathrm{C}$. Fruit leather yang dihasilkan memiliki kadar air $14,41 \%$, kadar abu 2,91\%, kadar gula total 48,91\%, kadar vitamin C 25,24 mg/10o, dan derajat keasaman (pH) 4,83. Uji sensori yang didapatkan pada perlakuan tersebut adalah warna orange kemerahan dengan nilai 3,51, rasa tidak begitu manis dengan nilai 3,71, tekstur agak kenyal dengan nilai 2,93, kesukaan keseluruhan sangat suka dengan nilai 3,67.
\end{abstract}

Kata kunci: buah naga merah, pepaya, fruit leather, suhu pengeringan.

\begin{abstract}
Red dragon fruit is a tropical fruit rich in antioxidants, but less preferred because it is not to sweet. Red dragon fruit is also very susceptible to damage due to high moisture content. Fruit leather is a type of processed food product derived from dried fruit pulp until the moisture content ranges from 10-15\%. Making fruit leather requires fruit high in fiber. The purpose of this research was to determine the characteristics of fruit leather with the ratio of red dragon fruit and papaya and to study the proper drying temperature to get good fruit leather characteristics.

The treatments included the ratio of papaya fruit: red dragon, ie 20:80, 30:70, and 40:60. The second treatment was drying temperature, i.e 140,150 , and $160^{\circ} \mathrm{C}$. The results showed that the ratio of red dragon fruit - papaya and drying temperature significantly affect the chemical characteristics and organoleptic fruit leather. Based on the research objectives obtained the best fruit leather in the ratio treatment of papaya flesh: dragon fruit meat (20:80) and drying temperature $140^{\circ} \mathrm{C}$. Fruit leather produced contained moisture content $14.41 \%$, ash content $2.91 \%$, total sugar content $48.91 \%$, vitamin C levels $25.24 \mathrm{mg} / 100$, acidity level $(\mathrm{pH}) 4.83$. Sensory test obtained in the treatment was a reddish orange color with a value of 3.51, not so sweet taste with a value of 3.71, slightly chewy texture with a value of 2.93, and the overall fondness was 3.67 .
\end{abstract}

Keywords: red dragon fruit, papaya, fruit leather, drying temperature.

Jurnal Teknologi dan Industri Pangan 4 (1): 7-14 


\section{PENDAHULUAN}

Buah naga memiliki rasa yang tidak begitu manis dibandingkan dengan buah lainnya sehingga kurang disukai apabila dikonsumsi dalam bentuk segar. Semua jenis buah segar bersifat mudah rusak dan memiliki umur simpan yang relatif singkat, sehingga perlu adanya alternatif pengolahan untuk mengatasi masalah tersebut. Mengolah buah menjadi fruit leather menjadi salah satu alternatifnya.

Fruit leather merupakan jenis olahan produk makanan yang berasal dari bubur daging buah yang dikeringkan sampai kadar air berkisar 10$15 \%$. Kriteria pembuatan friut leather ditentukan oleh kandungan serat, gula, dan asam. Bahan baku buah yang baik dalam pembuatan fruit leather adalah buah yang memiliki kandungan serat tinggi. Kandungan serat yang terdapat pada daging buah naga merah hanya sedikit, sehingga perlu dikombinasi dengan buah lain yang memiliki kandungan serat yang lebih tinggi seperti pepaya (Nurlaely, 2002).

Bahan pengisi diperlukan untuk memperbaiki tekstur dari fruit leather buah naga merah dan pepaya. Pada penelitian ini digunakan bahan pengisi yaitu tepung terigu. Bahan pengisi yang ditambahkan akan mengikat air dan diduga akan mempengaruhi tekstur dari fruit leather buah naga merah dan pepaya yang dihasilkan. Mutu fruit leather tergantung pada proses pengeringan. Proses pengeringan ditujukan untuk memperpanjang umur simpan dari fruit leather buah naga dan pepaya. Proses pengeringan akan mengakibatkan terjadinya perubahan warna, rasa, aroma dan tekstur. Oleh sebab itu, penelitian ini akan mengkaji suhu pengeringan yang optimal dalam pembuatan fruit leather buah naga merah dan pepaya sehingga diperoleh produk yang diterima oleh konsumen. Selain itu, penelitian ini bertujuan untuk mencari perbandingan terbaik antara buah naga merah dan pepaya yang menghasilkan fruit leather berkualitas baik dan disukai konsumen.

Fruit leather merupakan produk olahan yang terbuat dari bubur daging buah yang dikeringkan, berbentuk lembaran tipis, memiliki rasa dan warna yang khas seperti jenis buah sebagai bahan bakunya. Kadar air fruit leather adalah $10-15 \%$, sehingga memiliki umur simpan yang lebih panjang dibandingkan buah segar (Murdinah, 2010). Fruit leather terbuat dari satu atau campuran beberapa buah yang dihancurkan kemudian dikeringkan menjadi lembaran tipis yang memiliki ketebalan 2-3 $\mathrm{mm}$, rasa khas fruit leather tergantung dari buah yang digunakan serta memiliki umur simpan beberapa bulan (Safitri, 2012).

Sunarjono (2005) menerangkan bahwa dalam 100 gram daging buah naga terkandung $20 \mathrm{mg}$ vitamin C. Esquivel et al. (2007) dalam Budiman et al. (2017) menerangkan bahwa kandungan pigmen betalain pada buah naga merah berfungsi sebagai antioksidan. Hylocereus polyrhizus memiliki rasa yang sedikit asam, dan warna yang menarik. Buah naga (dragon fruit) mengandung zat bioaktif yang bermanfaat bagi tubuh di antaranya antioksidan berupa antosianin, betakaroten, dan asam askorbat, serta mengandung pektin.

Menurut Villegas (1997) dalam Susilowati (2007), dalam 100 gram bagian pepaya yang dapat dimakan mengandung 86,8 g air; 12,1 g karbohidrat; o,27 g serat; o,3 g lemak; 0,5 g protein; o, $5 \mathrm{~g}$ abu; o,o11 $\mathrm{g}$ fosfor; o,204 $\mathrm{g}$ kalium; o,o01 g besi; 0,45 g vitamin A; o,o75 g vitamin C; dan jenis gula utamanya terdiri dari $29,8 \%$ glukosa; 48,3 \% sukrosa; dan 21,9 \% fruktosa.

Di dalam tepung terigu terdapat gluten, yang secara khas membedakan tepung terigu dengan tepung lainnya. Gluten merupakan senyawa pada tepung terigu yang bersifat elastis dan kenyal, yang menentukan kekenyalan makanan, serta diperlukan dalam pembuatan makanan agar dapat mengembang dengan baik. Pada umumnya kandungan gluten menentukan kadar protein tepung terigu, semakin rendah kadar gluten, semakin rendah pula kadar protein tepung terigu tersebut. Jenis gandum yang digunakan menentukan kadar gluten pada tepung terigu dalam pembuatan suatu makanan yang berkualitas (Astuti, 2015).

Pengeringan merupakan proses pengeluaran air yang terkandung di dalam bahan pangan, dengan cara menguapkan atau menyublimasikan air tersebut (sebagian atau seluruhnya) dengan menggunakan energi panas. Penguapan air dalam bahan makanan menyebabkan kadar air bahan menjadi lebih rendah yang berakibat daya simpan bahan tersebut menjadi lebih lama. Hal ini terjadi karena jasad renik yang membusukkan dan memecahkan bahan pangan tidak dapat tumbuh karena ketiadaan air, serta enzim yang menyebabkan perubahan kimia yang tidak dikehendaki tidak dapat berfungsi tanpa adanya air (Desrosier, 1970). 


\section{METODE PENELITIAN}

Penelitian ini menggunakan rancangan acak lengkap faktorial, dengan dua faktor. Faktor I: Perbandingan buah pepaya : buah naga merah yaitu $\left(\mathrm{A}_{1}=20: 80 ; \mathrm{A}_{2}=30: 70 ;\right.$ dan $\left.\mathrm{A}_{3}=40: 60\right)$. Faktor II: Suhu pengeringan yaitu $\left(\mathrm{F} 1=140^{\circ} \mathrm{C}\right.$; $\mathrm{F}_{2}=10^{\circ} \mathrm{C}$; dan $\mathrm{F}_{3}=160^{\circ} \mathrm{C}$ ), sehingga diperoleh 9 kombinasi perlakuan dan masing-masing perlakuan diulang sebanyak 2 kali. Data yang diperoleh dianalisis dengan uji sidik ragam pada jenjang nyata 0,05 dan dilanjutkan dengan Duncan Multiple Range Test.

\section{Alat}

Alat yang digunakan dalam penelitian ini antara lain: peralatan penunjang, erlenmeyer, gelas ukur, timbangan (ohaus), oven (memmert), muffle (nabertherm), sentrifus (everlight), elektromantel (electrothermal) dan spektrofotometer (Genesys 1oS UV-VIS).

\section{Bahan}

Bahan yang digunakan dalam penelitian yaitu buah naga merah, pepaya, tepung terigu, asam sitrat, gula pasir dan bahan analisis antara lain 75-10o ml xylen, $10 \mathrm{mg}$ glukosa anhidrat/10o $\mathrm{ml}, 1 \mathrm{ml}$ reagensia nelson, $1 \mathrm{ml}$ reagensia arsen, $5 \mathrm{ml} \mathrm{HCl} 30 \%, \mathrm{NaOH}$ o,o1 N 45\%, $2 \mathrm{ml}$ larutan amilum $1 \%$, dan $1 \mathrm{ml}$ iodium.

\section{Tahapan Penelitian}

Buah naga merah dan pepaya dikupas, dicuci, dipotong kecil dan ditimbang sesuai perlakuan. Bahan lain ditimbang sehingga diperoleh hasil tepung terigu (30\%), gula pasir $(20 \%)$, dan asam sitrat (3\%). Daging buah diblender hingga halus. Kemudian dituang dalam baskom dan ditambah dengan bahan lain sambil diaduk perlahan hingga tercampur rata. Adonan dituang ke dalam loyang yang telah dilapisi kertas roti dan dioles margarin putih, dengan ketebalan $2 \mathrm{~mm}$. Lalu dimasukkan ke dalam oven dengan suhu pengeringan sesuai perlakuan selama \pm 100 menit.

Pengukuran dan pengamatan data dengan cara analisa terhadap parameter antara lain adalah analisis kadar air dengan metode Destilasi (AOAC, 1992), analisis kadar abu dengan metode Pengabuan (AOAC, 1992), analisis kadar gula total dengan metode Nelson-Somogyi (Sudarmadji et al, 1996), analisis kadar vitamin $\mathrm{C}$ dengan metode Titrasi Iodium (Sudarmadji et al, 2007), Analisis pH (Apriyantono, 1989), analisis uji organoleptik dengan metode Scoring test (Kartika et al, 1998) yang meliputi warna, rasa manis, tekstur lengket, dan kesukaan keseluruhan.

\section{HASIL DAN PEMBAHASAN}

Analisis Kimia

Tabel.1. Rangkuman Analisis Kimia Fruit Leather Buah Naga Merah - Pepaya dan Suhu Pengeringan.

\begin{tabular}{|c|c|c|c|c|c|c|}
\hline \multicolumn{2}{|c|}{ Perlakuan } & \multirow{2}{*}{$\begin{array}{l}\text { Kadar } \\
\text { Air } \\
(\%)\end{array}$} & \multirow{2}{*}{$\begin{array}{c}\text { Kadar } \\
\text { Abu } \\
(\%)\end{array}$} & \multirow{2}{*}{$\begin{array}{c}\text { Kadar } \\
\text { Gula Total } \\
(\%)\end{array}$} & \multirow{2}{*}{$\begin{array}{c}\text { Kadar } \\
\text { Vit. C } \\
(\%)\end{array}$} & \multirow{2}{*}{$\begin{array}{c}\text { Kadar } \\
\text { pH } \\
(\%)\end{array}$} \\
\hline $\begin{array}{l}\text { Perbandingan } \\
\text { Daging Buah }\end{array}$ & $\begin{array}{c}\text { Suhu } \\
\text { pengeringan } \\
\left({ }^{\circ} \mathrm{C}\right)\end{array}$ & & & & & \\
\hline \multirow{3}{*}{$20: 80$} & 140 & $14,41^{\mathrm{cd}}$ & $2,91^{\mathrm{C}}$ & $48,91^{\mathrm{b}}$ & $25,24^{\mathrm{e}}$ & $4,83^{c}$ \\
\hline & 150 & $13,29^{b}$ & $1,54^{\mathrm{b}}$ & $57,55^{\text {cde }}$ & $24,09^{c d}$ & $4,63^{\mathrm{ab}}$ \\
\hline & 160 & $11,61^{\mathrm{a}}$ & $1,15^{\mathrm{a}}$ & $62,59^{f}$ & $22,18^{\mathrm{b}}$ & $4,50^{a}$ \\
\hline \multirow{3}{*}{ 30:70 } & 140 & $14,87^{d}$ & $2,96^{c}$ & $48,19^{b}$ & $24,98^{\text {de }}$ & $4,83^{c}$ \\
\hline & 150 & $13,49^{b}$ & $1,55^{\mathrm{b}}$ & $55,90^{\mathrm{cd}}$ & $23,9^{c}$ & $4,67^{\mathrm{b}}$ \\
\hline & 160 & $11,62^{\mathrm{a}}$ & $1,17^{\mathrm{a}}$ & $59,57^{\mathrm{e}}$ & $21,92^{b}$ & $4,53^{\mathrm{ab}}$ \\
\hline \multirow{3}{*}{$40: 60$} & 140 & $14,84^{d}$ & $2,88^{c}$ & $45,38^{a}$ & $24,47^{\text {cde }}$ & $4,87^{\mathrm{c}}$ \\
\hline & 150 & $13,77^{\mathrm{bc}}$ & $1,55^{\mathrm{b}}$ & $55,10^{c}$ & $23,5^{c}$ & $4,67^{\mathrm{b}}$ \\
\hline & 160 & $11,06^{\mathrm{a}}$ & $1,14^{\mathrm{a}}$ & $58,34^{\mathrm{de}}$ & $20,68^{a}$ & $4,53^{\mathrm{ab}}$ \\
\hline
\end{tabular}




\section{Kadar Air}

Hasil analisis sidik ragam kadar air fruit leather buah naga merah - pepaya menunjukkan bahwa dengan perlakuan perbandingan daging buah pepaya:daging buah naga merah berbeda tidak nyata $(\alpha<0,05)$, sedangkan untuk perlakuan suhu pengeringan memiliki hasil yang berbeda nyata $(\alpha<0,05)$ terhadap kadar air fruit leather. Perlakuan kombinasi keduanya juga berbeda nyata $(\alpha<0,05)$.

Hasil analisis kadar air fruit leather buah naga merah - pepaya mengalami penurunan pada suhu pengeringan, semakin tinggi suhu pengeringan semakin rendah kadar air fruit leather buah naga merah - pepaya yang dihasilkan. Perbedaan kadar air pada fruit leather dipengaruhi oleh kandungan air pada bahan baku. Bahan baku yang digunakan mengandung kadar air yang hampir sama, sehingga pada perlakuan perbandingan daging buah memiliki hasil kadar air yang tidak jauh berbeda. Pada perlakuan suhu pengeringan kadar air semakin menurun seiring dengan semakin tinggi suhu pemanasan proses pengeringan fruit leather.

Hal ini selaras dengan pendapat Earle (1969) dalam Ningrum (2009), yang menerangkan bahwa semakin tinggi suhu pengeringan menyebabkan air semakin mudah menguap dan semakin lama pengeringan jumlah air yang diuapkan juga semakin meningkat. Menurut Ningrum (2009), itu disebabkan semakin tinggi suhu pengeringan, maka semakin tinggi pula energi panas yang diberikan maka air semakin mudah untuk menguap dan jumlah air yang diuapkan semakin banyak. Hasil tersebut sudah sesuai dengan standar kadar air fruit leather yaitu 10-15\% (Murdinah, 2010).

Pada penelitian ini diperoleh hasil kadar air fruit leather berkisar antara 11,06-14,87\% lebih rendah dibandingkan dengan kadar air fruit leather kombinasi buah pedada dan buah naga merah penelitian Rahman et al. (2016) yang berkisar antara 16,05-18,75\%. Hal ini disebabkan karena adanya perbedaan bahan baku dan perbedaan rasio pembuatan fruit leather.

\section{Kadar Abu}

Hasil analisis sidik ragam kadar abu fruit leather buah naga merah - pepaya menunjukkan bahwa dengan perlakuan perbandingan daging buah pepaya:daging buah naga merah yang berbeda yakni (20:80, 30:70, dan 40:60) memiliki hasil berbeda tidak nyata $(\alpha<0,05)$. Perlakuan suhu pengeringan memiliki hasil yang berbeda nyata $(\alpha<0,05)$ terhadap kadar abu fruit leather. Perlakuan kombinasi keduanya juga berbeda nyata $(\alpha<0,05)$.

Pada perlakuan suhu pengeringan kadar abu semakin menurun seiring dengan semakin tinggi suhu pemanasan proses pengeringan fruit leather. Hal ini disebabkan semakin tinggi suhu pengeringan, maka bahan menjadi semakin kering. Pada saat pembakaran dan pengabuan menggunakan muffle, zat-zat organik sisa hasil pembakaran dan pengabuan yang terdapat di dalam fruit leather buah naga merah - pepaya menjadi rendah dan kadar abunya semakin menurun. Kadar abu fruit leather dengan perlakuan perbandingan berbeda tidak nyata, hal ini disebabkan oleh karakteristik bahan baku yang hampir sama. Perlakuan suhu pengeringan dan kombinasi perlakuan keduanya berbeda nyata.

Kadar abu fruit leather buah naga merahpepaya pada penelitian ini berkisar antara 1,14-2,96\% lebih tinggi dibandingkan dengan fruit leather buah pedada-buah naga merah penelitian Rahman et al. (2016) yang berkisar antara o,48-1,13\%. Menurut Hadipernata dan Mulyana (2007), hal ini karena proses pengeringan menyebabkan terjadinya penguraian komponen ikatan molekul air, dan berefek pada kandungan mineral pada fruit leather sehingga menyebabkan kenaikan kandungan kadar abu dari fruit leather.

\section{Kadar Gula Tota}

Hasil analisis sidik ragam kadar gula total fruit leather buah naga merah - pepaya menunjukkan bahwa dengan perlakuan perbandingan daging buah pepaya:daging buah naga merah yang berbeda yakni (20:80, 30:70, dan 40:60) berpengaruh nyata $(\alpha<0,05)$ terhadap gula total fruit leather. Pada perlakuan suhu pengeringan dan pada perlakuan kombinasi keduanya juga memiliki hasil yang berbeda nyata $(\alpha<0,05)$ terhadap kadar gula total fruit leather.

Pada perlakuan perbandingan daging buah memiliki hasil yang berbeda nyata karena kandungan gula pada masing-masing bahan baku juga berbeda. Kandungan gula pada buah naga merah lebih besar dibanding kandungan gula pada pepaya, semakin banyak jumlah buah naga merah yang digunakan dan semakin sedikit jumlah buah pepaya yang digunakan maka semakin tinggi kadar gula yang dihasilkan. Kadar gula total fruit leather 
buah naga merah - pepaya mengalami kenaikan pada suhu pengeringan yang semakin tinggi. Hal ini disebabkan pada suhu pengeringan tinggi terjadi reaksi pemecahan gula kompleks (polisakarida, oligosakarida) menjadi gula sederhana (monosakarida, disakarida) dan menghasilkan air, oleh karena itu berimbas pada kelarutan.

Selaras dengan hasil penelitian Arief, et al (2005), yakni fruit leather stroberi yang dihasilkan memiliki kadar gula total yang meningkat seiring dengan semakin tinggi suhu pengeringan. Hal ini menunjukkan semakin tinggi suhu pengeringan yang digunakan, maka semakin tinggi kadar gula total yang dihasilkan. Hal tersebut dapat terjadi karena pada proses pengeringan dengan suhu tinggi, air yang diuapkan semakin banyak sehingga jumlah padatan terlarut dalam bahan akan semakin meningkat, sehingga dapat meningkatkan kadar gula total dari fruit leather.

\section{Kadar Vitamin C}

Hasil analisis sidik ragam menunjukkan bahwa perlakuan perbandingan daging buah pepaya:daging buah naga merah, suhu pengeringan, dan pada perlakuan kombinasi keduanya berpengaruh nyata $(\alpha<0,05)$ terhadap kadar vitamin C fruit leather. Kadar vitamin C fruit leather pada penelitian ini berkisar antara 20,68-25,25\% lebih rendah dibandingkan dengan fruit leather jambu biji merah dan sirsak penelitian Astuti et al. (2016) dengan kadar vitamin $\mathrm{C} 80-82 \%$ (suhu pengeringan $50^{\circ} \mathrm{C}$ ). Hal ini disebabkan oleh suhu pengeringan yang berbeda.

Pada perlakuan perbandingan memimiliki hasil kadar vitamin $C$ semakin menurun. Kandungan vitamin $C$ pada buah naga merah lebih tinggi dibanding buah pepaya, semakin banyak jumlah buah naga merah yang digunakan dan semakin sedikit jumlah buah pepaya yang digunakan maka semakin tinggi vitamin $C$ yang dihasilkan pada analisis kimia fruit leather. Pada perlakuan suhu pengeringan memiliki hasil kadar vitamin $C$ semakin menurun. Penurunan vitamin C pada fruit leather disebabkan karena panas yang tinggi pada saat pengeringan. Sesuai dengan pendapat Winarno (1991) yang menerangkan bahwa vitamin $C$ mempunyai sifat mudah teroksidasi, penyebab kerusakan vitamin $C$ yang lain adalah panas, temperatur tinggi, dan enzim oksidase.

\section{Derajat Keasaman (pH)}

Hasil analisis sidik ragam menunjukkan bahwa pH dari fruit leather pada perlakuan perbandingan daging buah pepaya:daging buah naga merah memiliki hasil berbeda tidak nyata $(\alpha<0,05)$. Perlakuan suhu pengeringan dan pada perlakuan kombinasi keduanya berbeda nyata $(\alpha<0,05)$. Nilai $\mathrm{pH}$ pada fruit leather buah pedada-buah naga merah penelitian Rahman et al. (2016) berkisar antara 3,11-4,23 lebih rendah dibandingkan $\mathrm{pH}$ fruit leather pada penelitian ini yakni berkisar antara 4,50-4,87. Hal ini disebabkan karena perbedaan bahan baku dan rasio bahan.

Pada perlakuan suhu pengeringan memiliki hasil nilai $\mathrm{pH}$ semakin menurun seiring dengan semakin tinggi suhu pengeringan. Semakin tinggi suhu menunjukkan produk semakin basa sehingga nilai $\mathrm{pH}$ semakin turun. Pada perlakuan perbandingan tidak berpengaruh nyata. Semakin banyak jumlah daging buah pepaya yang digunakan dan semakin sedikit jumlah daging buah naga merah yang digunakan, maka nilai $\mathrm{pH}$ pada fruit leather akan semakin meningkat secara signifikan. Sebaliknya, semakin sedikit jumlah daging buah pepaya yang digunakan dan semakin banyak jumlah daging buah naga merah yang digunakan, maka nilai $\mathrm{pH}$ fruit leather semakin rendah. Hal ini disebabkan kandungan asam askorbat pada daging buah pepaya lebih tinggi yaitu 46,89 mg (Cresna et al, 2014). Menurut Taiwan Food Industry Development \& Research Authorities (2000) asam askorbat yang terkandung didalam buah naga jauh rendah yaitu hanya 9,40 mg. Semakin tinggi asam yang terkandung pada suatu bahan pangan, maka rasa akan semakin asam dan nilai $\mathrm{pH}$-nya akan semakin rendah (Fardiaz, 1992 dalam Rahman et al, 2016). 
Analisis Sensori

Tabel.2. Rangkuman Analisis Kimia Fruit Leather Buah Naga Merah - Pepaya dan Suhu Pengeringan.

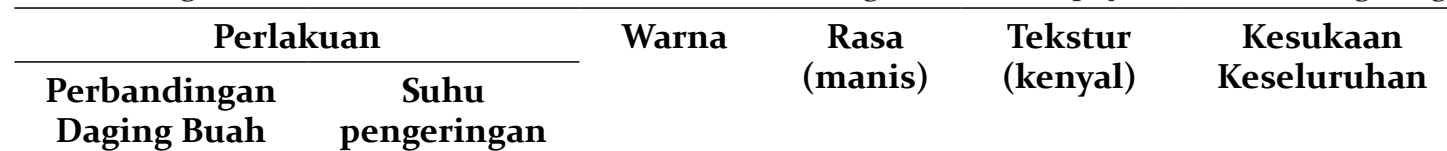

$\left({ }^{\circ} \mathrm{C}\right)$

\begin{tabular}{llllll}
\hline & 140 & $3,51^{\mathrm{c}}$ & $3,71^{\mathrm{c}}$ & $2,93^{\mathrm{c}}$ & $3,67^{\mathrm{bc}}$ \\
$20: 80$ & 150 & $2,47^{\mathrm{b}}$ & $2,67^{\mathrm{b}}$ & $1,60^{\mathrm{b}}$ & $4,53^{\mathrm{e}}$ \\
& 160 & $1,61^{\mathrm{a}}$ & $1,75^{\mathrm{a}}$ & $1,24^{\mathrm{a}}$ & $4,21^{\mathrm{de}}$ \\
\hline \multirow{2}{*}{$30: 70$} & 140 & $3,44^{\mathrm{c}}$ & $3,81^{\mathrm{c}}$ & $2,29^{\mathrm{c}}$ & $3,61^{\mathrm{ab}}$ \\
& 150 & $2,50^{\mathrm{b}}$ & $2,65^{\mathrm{b}}$ & $1,68^{\mathrm{b}}$ & $4,43^{\mathrm{e}}$ \\
& 160 & $1,79^{\mathrm{a}}$ & $1,73^{\mathrm{a}}$ & $1,21^{\mathrm{a}}$ & $4,01^{\mathrm{cd}}$ \\
\hline \multirow{2}{*}{$40: 60$} & 140 & $3,39^{\mathrm{c}}$ & $4,17^{\mathrm{d}}$ & $2,28^{\mathrm{c}}$ & $3,52^{\mathrm{a}}$ \\
& 150 & $2,54^{\mathrm{b}}$ & $2,58^{\mathrm{b}}$ & $1,52^{\mathrm{b}}$ & $4,05^{\mathrm{d}}$ \\
& 160 & $1,66^{\mathrm{a}}$ & $1,73^{\mathrm{a}}$ & $1,21^{\mathrm{a}}$ & $3,43^{\mathrm{ab}}$ \\
\hline
\end{tabular}

Keterangan:

1. Warna : nilai tertinggi menunjukkan fruit leather buah naga merah - pepaya orange kemerahan.

2. Rasa (manis): nilai tertinggi menunjukkan fruit leather buah naga merah - pepaya tidak begitu manis.

3. Tekstur (kenyal): nilai tertinggi menunjukkan fruit leather buah naga merah - pepaya kenyal.

4. Kesukaan Keseluruhan: nilai tertinggi menunjukkan fruit leather buah naga merah - pepaya disukai.

\section{Warna}

Hasil analisis sidik ragam uji organoleptik warna fruit leather buah naga merah - pepaya dan suhu pengeringan menunjukkan bahwa perlakuan perbandingan daging buah, suhu pengeringan, dan pada perlakuan kombinasi keduanya berpengaruh nyata $(\alpha<0,05)$ terhadap warna fruit leather. Semakin tinggi suhu pengeringan, ada kecenderungan warna fruit leather buah naga merah - pepaya semakin orange kecoklatan. Hal ini disebabkan karena pada proses pengeringan yang menggunakan suhu pengeringan tinggi dengan katalis asam atau basa, gula pereduksi akan mengalami karamelisasi (Yis, 2009 dalam Ningrum, 2009).

Parameter warna yang paling tinggi pada perbandingan daging buah pepaya:daging buah naga merah (20:80) dan pada suhu pengeringan $140^{\circ} \mathrm{C}$ dengan nilai 3,51. Sebaliknya parameter warna yang paling rendah pada perbandingan daging buah pepaya:daging buah naga merah (20:80) dan pada suhu pengeringan $140^{\circ} \mathrm{C}$ dengan nilai 1,61. Semakin tinggi nilai memiliki arti bahwa warna dari fruit leather buah naga pepaya dan suhu pengeringan semakin merah keunguan dan semakin rendah nilai memiliki arti bahwa warna dari fruit leather buah naga pepaya dan suhu pengeringan semakin merah pucat.

\section{Rasa manis}

Hasil analisis sidik ragam uji organoleptik rasa manis pada perlakuan perbandingan daging buah pepaya:daging buah naga merah berbeda tidak nyata $(\alpha<0,05)$. Perlakuan suhu pengeringan dan pada perlakuan kombinasi keduanya berbeda nyata $(\alpha<0,05)$ terhadap rasa manis fruit leather. parameter rasa manis paling tinggi pada perbandingan daging buah pepaya:daging buah naga merah (40:6o) dan pada suhu pengeringan $160^{\circ} \mathrm{C}$ dengan nilai 4,17. Sebaliknya parameter rasa manis paling rendah pada perbandingan daging buah pepaya:daging buah naga merah (40:60) dan pada suhu pengeringan $160^{\circ} \mathrm{C}$ dengan nilai 2,82 . Semakin tinggi nilai dari parameter rasa memiliki arti bahwa rasa manis dari fruit leather buah naga - pepaya dan suhu pengeringan semakin manis dan sebaliknya.

Rasa manis dari fruit leather tidak begitu manis. Hal ini dikarenakan penggunaan bahan dasar buah naga merah yang memiliki rasa tidak begitu manis dari buah lainnya dan pepaya yang masak optimal memiliki rasa cenderung hambar (tidak terasa manis).

Hasil organoleptik rasa manis berbanding terbalik dengan hasil analisis kimia gula total, hal ini disebabkan oleh faktor-faktor lain seperti human error. Human error disebabkan oleh beberapa faktor, antara lain pencahayaan, 
panelis sakit, penurunan kepekaan panelis, dan lain-lain.

\section{Tekstur Kenyal}

Menurut Ningrum (2009), dalam penilaian tekstur bahan pangan melalui indera perabaan terdapat hampir di seluruh permukaan kulit dengan kepekaan yang berbeda seperti rongga mulut, bibir, dan tangan mempunyai kepekaan yang tinggi terhadap perabaan. Hasil analisis sidik ragam uji organoleptik tekstur (kenyal) fruit leather buah naga merah - pepaya dan suhu pengeringan menunjukkan bahwa pada perlakuan perbandingan daging buah memiliki hasil berbeda tidak nyata $(\alpha<0,05)$ terhadap uji organoleptik tekstur (kenyal). Perlakuan suhu pengeringan dan pada perlakuan kombinasi keduanya berpengaruh nyata $(\alpha<0,05)$ terhadap uji organoleptik tekstur kenyal dari fruit leather.

Hasil analisis uji organoleptik tekstur (kenyal) yang paling tinggi adalah pada perlakuan perbandingan daging buah pepaya:daging buah naga merah (20:80) dan pada perlakuan suhu pengeringan $140^{\circ} \mathrm{C}$ dengan nilai 2,49 . Sebaliknya hasil analisis uji organoleptik tekstur (kenyal) yang paling rendah adalah pada perlakuan perbandingan daging buah pepaya:daging buah naga merah (30:70 dan 40:60) dan pada perlakuan suhu pengeringan $160^{\circ} \mathrm{C}$ dengan nilai 1,21. Hal ini disebabkan semakin tinggi suhu pengeringan, maka produk pangan yang dihasilkan semakin kering dan kehilangan sifat plastis atau kenyal.

\section{Kesukaan keseluruhan}

Hasil analisis sidik ragam uji organoleptik kesukaan keseluruhan fruit leather buah naga merah - pepaya menunjukkan bahwa perlakuan perbandingan daging buah dan perlakuan suhu pengeringan berpengaruh nyata $(\alpha<0,05)$ terhadap uji organoleptik kesukaan keseluruhan fruit leather buah naga merah - pepaya yang dihasilkan. Perlakuan kombinasi keduanya menunjukkan pengaruh yang tidak berbeda nyata $(\alpha<0,05)$ terhadap uji organoleptik kesukaan keseluruhan fruit leather buah naga merah - pepaya.

Kesukaan keseluruhan yang paling tinggi terdapat pada perlakuan perbandingan daging buah pepaya:daging buah naga merah (20:80) dan pada perlakuan suhu pengeringan $150^{\circ} \mathrm{C}$. Hal ini disebabkan karena fruit leather buah naga merah - pepaya dengan perlakuan tersebut mempunyai warna orange kemerahan, rasa manis tidak begitu manis, dan tekstur kenyal.

\section{KESIMPULAN}

Perlakuan terbaik dari parameter yang telah diuji dan memenuhi BSN - SNI o11718-1996 adalah perbandingan daging buah pepaya:daging buah naga merah (20:80) dan suhu pengeringan $150^{\circ} \mathrm{C}$. Fruit leather yang dihasilkan memiliki nilai kadar air 13,29\%, kadar abu 1,54\%, kadar gula total 57,55\%, kadar vitamin C 24,09\%, dan kadar $\mathrm{pH} 4,63$. Uji sensori yang didapatkan pada perlakuan tersebut adalah warna merah keunguan dengan nilai $2,47 \%$, rasa tidak begitu manis dengan nilai $2,67 \%$, tekstur agak kenyal dengan nilai 1,60\%, kesukaan keseluruhan sangat suka dengan nilai $4,53 \%$.

\section{DAFTAR PUSTAKA}

Apriyantono, A., 1989. Petunjuk Laboratorium Analisis Pangan. PAU Pangan dan Gizi. Bogor: Institut Pertanian Bogor.

Arief , D. Z., Ikrawan, Y., dan Rahmawaty, R., 2005. Pengaruh Konsentrasi Pektin dan Suhu Pengeringan Terhadap Karakteristik Fruit Leather Stroberi (Fragaria chiloensis L). INVOMATEK. Volume 7. No.1.

Association of Official Analytical Chemist, 1992. Official Methods of Analysis. Washington: AOAC.

Astuti, N. D., 2015. Karakteristik Stik Jambu Merah (Psidium guajava L.) Dengan Substitusi Tepung Maizena. Skripsi. Surakarta: Fakultas Teknologi dan Industri Pangan, UNISRI.

Astuti, W. F. P., Nainggolan, R. J., dan Nurminah, M., 2016. Pengaruh Jenis Zat Penstabil dan Konsentrasi Zat Penstabil Terhadap Mutu Fruit Leather Campuran Jambu Biji Merah dan Sirsak. Ilmu dan Teknologi Pangan J. Rekayasa Pangan dan Pert. Vol. 4 No.1.

Budiman, Hamzah, F., dan Johan, V. S., 2017. Pembuatan Selai dari Campuran Buah Sirsak (Annona muricata L.) dengan Buah Naga Merah (Hylocereus polyrhizus). JOM Faperta. Vol. 4 No.2. Oktober 2017.

Cresna, Napitupulu, M., dan Ratman., 2014. Analisis Vitamin C Pada Buah Pepaya, Sirsak, Srikaya Dan Langsat Yang Tumbuh Di Kabupaten Donggala. J.Akad. 
Kim. Vol. 3 No. 3.

Desrosier, N. W., 1988. Teknologi Pengawetan Pangan. Edisi III. Penerjemah

Muchji Mulyohardjo. Jakarta:Universitas Indonesia.

Esquivel, P., Stinzing, F. C., dan Carle, R., 2007. Fruit characteristics during growthand ripening of different hylocereus genotypes. European Journal of Horticultural Science. Vol (72): 231238.

Fardiaz, S., 1992. Mikrobiologi Pangan 1. Jakarta: PT. Gramedia PustakaUtama. 320 hlm.

Hadipernata, dan Mulyana., 2007. Mengolah Dedak Menjadi Minyak (Rice Bran Oil). Jurnal Penelitian dan Pengembangan Pertanian. (29): 8-10.

Kartika, B. D., Hastuti, W., Supratno., 1998. Pedoman Uji Inderawi Bahan Pangan. Yogyakarta: PAU Pangan dan Gizi Universitas Gajah Mada.

Murdinah, 2010. Penelitian Pemanfaatan Rumput Laut Dan Fikokoloid Untuk Produk Pangan dalam Rangka Peningkatan Nilai Tambah dan Verifikasi Pangan. Jakarta: Badan Penelitian dan Pengembangan Kelautan dan Perikanan.

Ningrum, S. D. U., 2009. Fruit Leather Pepaya (Carica papaya L.) Dengan Variasi Jenis Tepung dan Suhu Pengeringan. Skripsi. Surakarta: Fakultas Teknologi dan Industri Pangan, UNISRI.

Nurlaely, E., 2002. Pemanfaatan Buah Jambu Mete untuk Pembuatan leather kajian dari proporsi buah pencampur. Skripsi. Malang: Jurusan Teknologi Hasil Pertanian. Universitas Brawijaya.

Rahman, R., Pato, U., dan Harun, N., 2016. Pemanfaatan Buah Pedada (Sonneratia caseolaris) Dan Buah Naga Merah (Hylocereus polyrhizus) Dalam Pembuatan Fruit Leather. JOM Faperta. Vol. 3 No.2.

Ramadhan, M. R., Harun, N., dan Hamzah, F., 2015. Kajian Pemanfaatan Buah Naga Merah (Hylocereus polyrhizus) dan Mangga (Mangifera indica Linn) Dalam Pembuatan Fruit Leather. Jurnal SAGU. Vol. 14 No. 1 23-31.

Safitri, A. A., 2012. Studi Pembuatan Fruit Leather Mangga dan Rosella. Skripsi. Makasar: Fakultas Pertanian. Universitas Hasanuddin.

Sudarmadji, S., Bambang, H., Suhardi, 2007. Analisa Bahan Makan dan Pertanian. Yogyakarta: Liberty.

Sunarjono, H., 2005. Sirsak dan Srikaya Budidaya untuk Menghasilkan Buah Prima. Jakarta: Penebar Swadaya.

Susilowati, R., 2007. Pendugaan Parameter Mutu Buah Pepaya (Carica papaya L.) dengan Metode Near Infrared Selama Penyimpanan dan Pemeraman. Skripsi. Bogor: Fakultas Teknologi Pertanian, Institut Pertanian Bogor.

TFIDRA, 200o. Report code "85-2537". Taiwan: Taiwan Food Industry Development \& Research Authorities.

Villegas, V. N., 1997. Carica papaya L. In: EWM Verheij, RE Coronel,eds. Plant Resources of South-East Asia 2: Edible Fruits and Nuts. Bogor: PROSEA Foundation.

Winarno, F. G., 1991. Kimia Pangan dan Gizi. Edisi 3. Jakarta: PT. Gramedia Pustaka Utama.

Yis, 2009. Sifat Fisikokimia Karbohidrat. Yongkikastanyaluthana.wordpr [5 Juni 2018 jam 15.50]. 